\title{
The Realization Way of Strategic Development of Colleges and Universities in Yunnan Province in the Background of "The Belt and Road"
}

\author{
Chongyou Ruan* \\ The College of Arts and Sciences \\ Yunnan Normal University \\ Kunming, China \\ 807756298@qq.com
}

\author{
Minna Wu \\ The College of Arts and Sciences \\ Yunnan Normal University \\ Kunming, China
}

\begin{abstract}
The silk road has promoted economic exchanges and cultural integration between China and foreign countries, and the strategy of "The Belt and Road" has established a new pattern of all-round opening up for our country. At present, the colleges and universities in Yunnan province should seize the opportunity of international cooperation and exchanges, actively integrated into the strategy of "The Belt and Road", bring their superiority into full play, improve the level of school-running and actively "go out and introduce in".
\end{abstract}

Keywords-"The Belt and Road" strategy; the colleges and universities in Yunnan province; strategic development

\section{INTRODUCTION}

Yunnan plays significant roles in the following fields including one of the important bridgeheads for the openness of southwest area in our country, the strategic fulcrum of the connection and intersection in "The Belt and Road" construction, the communication channel between south Asia countries and southeast Asia countries, the significant base of major industry transfer and industry agglomeration, the important platform and window in the exchanges and cooperation with south Asia countries and southeast Asia countries. The unique location advantage of Yunnan province highlights its status in "The Belt and Road" construction [1].

The initiative of "The Belt and Road" is the top-level design for the international education cooperation and exchange, which has clear requirements for the development of colleges and universities. In February 2016, the General Office of the Central Committee of the Communist Party of China and the General Office of the State Council issued "The Several Opinions about the Accomplishment of Opening-up Work of Education in the New Period" (hereinafter referred to as "Opinions"). The Opinions puts forward that the central and western regions in our country should expand their breadth and depth of the opening-up work of education, the border areas should take advantage of their geographical superiority to promote the education cooperation and exchange with neighboring countries and form a opening-up pattern that adjust to local conditions and with the development of characteristics. In August 2016, for the implementation of the "Opinions", the ministry of education formulate the action of
"The Promotion Campaign to the establishment of 'The Belt and Road' Education". The action points out that, in order to highlight the features of subjectivity, support and popularity of the promotion campaign in local area, the local government should take advantage of location superiority and local characteristics get close connection with the general layout of our country and schools at all levels should expand cooperation and exchanges with schools of various countries that along "The Belt and Road" and jointly promote education internationalization level and the service capability of "The Belt and Road" construction. The colleges and universities in Yunnan province, as the talent support for the need of "The Belt and Road" construction in the southwest region and the important subject of culture communication in the countries along "The Belt and Road", are responsible for the foreign exchange and cooperation.

\section{YunNAN PROVINCE SHOULD ACTIVELY INTEGRATE INTO “THE BELT AND ROAD” STRATEGY}

"The Belt and Road" strategy will help further improve China's opening-up standards and build a new pattern of allround opening-up. The colleges and universities in Yunnan Province should also take advantage of the situation, combine with the reform of education, actively integrate into "The Belt and Road" strategy, seize development opportunities and enhance the comprehensive strength [2].

\section{A. Seizing Development Opportunities and Serving "The Belt and Road" Construction}

In the process of " the Belt and Road" construction, both economic and trade cooperation and cultural exchange are need interdisciplinary talents with the following features including having international vision, the familiarity of international rules, the master capability of a foreign language as well as having professional research about a country, region or industry fields. The colleges and universities in Yunnan Province should, according to the situation of opening-up level and talent demand in the region, combining the discipline construction and the reality of teaching and scientific research, reform and innovate personnel training mode, highlight the key areas and majors with characteristics, actively participate in and deeply

*Corresponding author 
integrate into "The Belt and Road" construction. The colleges and universities in Yunnan province should release their vitality in the reform, tap the potential in innovation, and promote the transformation from the epitaxial development to the internal development, so as to realize the characteristic development and sustainable development.

For the cultivation of international talents, the colleges and universities in Yunnan province should have an international vision, promote opening-up education in an all round way and promote internationalization level. The colleges and universities in Yunnan province should actively study the following fields including economic and social development situation, personnel training situation and talent demand situation in the country's that included in "The Belt and Road" strategy in order to accurately grasp the different needs of different countries and different regions, take the actual demand as orientation, explore and innovate various cultivation methods including directional commission cultivation, ordering cultivation, project joint orientation, expand the scale of foreign students education, 'build international students internship and practice teaching platform, establish characteristic majors and high quality courses, deepen the reform of education and teaching, continuously improve the education quality for international students, cultivate talents that fit the demand of economic development and social progress among other countries and further serve "The Belt and Road" construction [3].

\section{B. Taking Full Advantages of Own Superiority and}

\section{Integrating into "The Belt and Road" Construction}

The colleges and universities in Yunnan province should give full play to their advantages, strengthen their own characteristics, have precise positioning, consolidate their own advantages, integrate with the social demand, have different development routine with other colleges and universities, have clear planning toward the discipline construction, provide the necessary talent support and the think-tank service for the social and economic development and integrate into "The Belt and Road" construction.

The colleges and universities in Yunnan province should determine their key development direction according to the positioning of this region in "The Belt and Road" strategy and realize the new development in the construction of "The Belt and Road". Yunnan, as the frontier region in the construction of "the economic belt of silk road", has superior geographical condition for its geographical location is border with Myanmar, Laos, Vietnam and other countries has become a bridgehead now in our country's southwest opening-up work. The colleges and universities in Yunnan province, based on their advantage in geographical condition, actively carry out foreign exchanges activities, cooperate with colleges and universities in southeast Asia and south Asia, actively explore the international horizon and improve the level of education.

\section{THE NEW IDEA FOR THE IMPLEMENTATION OF STRATEGIC DEVELOPMENT IN THE COLLEGES AND UNIVERSITIES IN YUNNAN PROVINCE UNDER THE INITIATIVE OF "THE BELT AND ROAD"}

\section{A. Practicing Internationalized Education Ideas}

China is speeding up the construction of opening economic system, which objectively requires us to strengthen the concept of opening-up education and the concept of internationalization, and promote the process of opening-up and internationalization in an all round way. Under the background of "The Belt and Road" strategy, the colleges and universities in Yunnan province should actively explore and carry out the high level school running under the international vision, promote the reform of education system and promote the development of the school.

The international vision of higher education is a global feeling, and the first thing is the respect for the diversity of human civilization. The key for the colleges and universities in Yunnan province to running school in a high level under the international vision is that the colleges and universities in Yunnan province should have international mind and tolerance, bold and absorb foreign advanced ideas of higher education, introduce high-quality international resources in personnel training, school management the construction of teachers team and so on, gradually construct a high level platform for the international cooperation, create a good international school atmosphere, improve the quality of international education and, at the sane time, promote the school's international influence.

From the perspective of the colleges and universities in Yunnan province to running school in a high level under the international vision, the colleges and universities in Yunnan province should actively use the international high quality education resources, innovate talent training mechanism, deepen teaching reform, strengthen the construction, of characteristic major, promote the cultivation of interdisciplinary talents and the school running with high level and characteristics at the same time, improve the quality of personnel training, enhance the level of scientific research, enhance social service ability and eventually enhance the international competitiveness of the colleges and universities in Yunnan province.

The colleges and universities in Yunnan province should set autonomous right by the utilization of good major and the establishment of major should be based on the support and guarantee of courses that are provided by related disciplines in the training program. The colleges and universities in Yunnan province should step by step achieve the optimal allocation of professional teaching resources, excavate potential academic resources, release the energy of talent training. Teaching resources sharing is an important symbol of high level education in the colleges and universities in Yunnan province, relying on modern information technology, the colleges and universities in Yunnan province build sharing network platform, promote the quality of online teaching resources and expand the coverage of high quality education resources. In the process of the "The Belt and Road" construction, the colleges and universities in Yunnan province should voluntarily integrate with the world-class colleges and universities and 
actively integrate into the international education system, thus improving the international level of the school.

The colleges and universities in Yunnan province should, based on the existing situation of China and foreign cooperation in running schools, promote the level of communication and cooperation in teaching and scientific research, gradually form the world's advanced system of exchanges and cooperation with Chinese characteristics, promote the establishment of the new cooperation relationship with foreign universities, companies and even industries continue to expand the scale of foreign education and deepen the high-level cooperation between personnel training and personnel exchanges.

\section{B. Strengthening the Construction of Connotation}

In the future, the colleges and universities in Yunnan province should accelerate the construction of high-level colleges and university, actively build 12 "International University". The construction of "International University" will further enlarge the radiation of Yunnan to southeast Asia and south Asia and provide manpower support and intellectual support for the international cooperation and exchange in southeast Asia and South Asia, thus lading a solid foundation for the building of Yunnan into the international talent training base toward southeast Asia and South Asia. On the above basis, the colleges and universities in Yunnan province should focus on the following two tasks.

First, the colleges and universities in Yunnan province should strengthen the construction of teachers and faculties, send teachers to foreign universities for further study, improve their international communication skills, and establish a longterm mechanism for the academic and exchange visits of teacher teams and management cadres, meanwhile, employ foreign excellent teachers to conduct scientific research and teaching. Second, the colleges and universities in Yunnan province should continue to increase the cultivation of minor language talents, expand the scale of talent cultivation for the languages of countries in southeast Asia and south Asia, improve the quality of talent cultivation., continue to increase the overall planning for the languages of countries in southeast Asia and south Asia, set up language majors of the urgent needed languages of countries in southeast Asia and south Asia, offer preferential policy and funding support for these new founded language majors, optimize the structure of minor language disciplines and implement the compound talents training mode of "language + major" [4].

\section{Promoting the Construction of the Think-tank Service in Colleges and Universities}

Strengthening the construction of new think-tank service is a strategic measure of the modernization of national governance system and governance capability, and is an important part of national soft power. For the perspective of pushing forward the construction of the new think-tank service in colleges and universities with Chinese characteristics, the colleges and universities in Yunnan province have certain advantages including resource advantage, talent advantage and disciplines advantage. The colleges and universities in Yunnan province should provide high level intellectual support and talent support for the party and the government in the the following fields including thought enlightenment, cultural inheritance, foreign exchange and decision-making advice [5].

The think-tank service in colleges and universities should serve the national strategic needs. In the context of "The Belt and Road" strategy, The think-tank service in the colleges and universities in Yunnan province should bring their subject and talent advantages into full play, solve realistic problems by a interdisciplinary and multi-angle way, provide decision-making thought for the government, actively carry out research toward politics, economy, culture, education, environment and society in the countries of southeast Asia and south Asia, give attention to discipline construction and the social demand at the same time and establish a "think tank" of problems research of countries in southeast Asia and south Asia and the innovation center of the surrounding international relations theory.

The construction of think-tank service in the colleges and universities in Yunnan province should around the solution of important practical problems, especially the hot and difficult problems in the economic development of local society, the improvement of the pertinence and efficiency in the study and the research achievements of high level and high quality in policy recommendations.

\section{Actively "Go out and Introduce in"}

First of all, the colleges and universities in Yunnan province should actively seek the support of the ministry of education, greatly increase the number of Chinese government scholarships and Confucius institute scholarships, strive for provincial financial support, and increase the support of Yunnan provincial government scholarship. At the same time, the colleges and universities in Yunnan province should actively participate in China-ASEAN's double a-hundredthousand students flow plan and ten-thousand youth exchange program, so as to expand the scale of students studying in Yunnan and expand the enrollment of high-quality students. And the colleges and universities in Yunnan province should further improve the training system of overseas students and ensure the quality and management level of education, so as to enhance the attractiveness of the colleges and universities in Yunnan province to overseas students.

Secondly, the colleges and universities in Yunnan province should actively implement the "International Exchanges and Cooperation Project", strive for the support of Dffice of Chinese Language Council International, pushing forward the class construction of the Confucius Institute in Yunnan province, establish Chinese language center, Chinese cultural center, Chinese promotion base in the countries of southeast Asia and south Asia In addition, some qualified colleges and universities in Yunnan province should should strive to establish branch campuses in the countries of southeast Asia and south Asian and increase students' overseas exchanges activities.

Thirdly, the colleges and universities in Yunnan province should combine the development characteristics of Yunnan province and colleges and universities to create diversified and distinctive cooperation situation so as to avoid the vicious 
competition caused by homogenization development. For example, we give full play to the advantages of language training in Yunnan Normal University and actively carry out the training and project of TCSL. We give full play to the advantages of Kunming University of Science and Technology and jointly train international engineering talents. We give full play to the advantages of minority languages in Yunnan University of Nationalities and jointly cultivate international trade talents who are proficient in southeast Asia and south Asia. We give full play to the advantages of agricultural science and technology technology of Yunnan Agricultural University and the advantages of forestry science and technology of Southwest Forestry University and jointly carry out research project research and personnel training [6].

\section{E. Conducting Intercultural Communication}

Under the multicultural background, the international talents cultivated by the colleges and universities in Yunnan province for the "The Belt and Road" construction should possess certain cross-cultural communication ability and independent ability of international activities, carry forward and inherit the spirit of the silk road and "going out" at the same time and promote the communication between different cultures.

In international exchanges and cooperation, the colleges and universities in Yunnan province should actively explore, have the courage to bear and take the initiative to express the basic idea that China is willing to work with the country's that included in "The Belt and Road" deepen cultural exchanges, and shares the development achievements.

Under the background of "The Belt and Road" strategy, in the intercultural communication and communication, the colleges and universities in Yunnan province should give full play to the advantages of "Confucius Institute" in order to enable the people all over the world have the zero distance "close contact" with Chinese culture, promote cultural exchanges and education cooperation between different countries, promote national feelings and closely and friendly exchanges, share development efforts and create a better future.

\section{CONCLUSION}

"The Belt and Road" strategy has rich and profound connotation, will fully enhance the level of social and economic development in our country, with the pragmatic cooperation of countries along the belt, our country establishes new type of national relations with the features of political mutual trust, economic integration and cultural mutual capacitance. The colleges and universities in Yunnan province should seize the opportunity, actively integrated into the national "The Belt and Road" development strategy, based on the characteristics, enhance the school level, integrate the advantage resources and construct the new think-tank service, broaden the international perspective and boost cultural blend, serve social and economic development and, at the same time, realize their own connotative, tremendous and sustainable development.

\section{REFERENCE}

[1] Zhu Xiongguan, Jiang Jin. Analysis of Advantages and Countermeasures of Yunnan in"The Belt and Road" strategy [J]. Journal of Chuxiong Normal University, 2015(4).

[2] Wang Yanxin. "The Belt and Road" Strategy Leads the Internationalization of Education [N]. Guangming daily, 2015-05-26.

[3] Li Fengliang. Internationalization of Higher Education Must Pay Attention to Student Affairs Management [N]. China Science News, 2014-12-25

[4] Li Huiqin, Li Hongqian, Wang Yun. Research on Communication and Cooperation OF Higher Education Between Yunnan Province and Southeast Asian [J]. Education Research, 2010 (2)

[5] Ge Jianxiong. University Think Tank: Outstanding Characteristics and Advantages [N]. Guangming daily, 2015-05-27.

[6] Zhu Huashan, Yi Jidong, Wang Yongquan. Development Research of Higher Education in Yunnan Province [M]. Kunming: Yunnan Publishing Group, 2014. 